\title{
ROLE OF FACEBOOK VIDEO ADVERTISEMENTS IN INFLUENCING THE IMPULSIVE BUYING BEHAVIOR OF CONSUMERS
}

\author{
Dr. Amit Chawla \\ Associate Professor and Head of Department \\ School of Media, Film and Entertainment - Sharda University \\ Department of Mass Communication, \\ Greater Noida, UP
}

\begin{abstract}
The purpose of this study is to empirically investigate the role of Facebook video advertisements in influencing the impulsive buying behavior of consumers. Social media facilitates global interaction among its users through their experiences and ideas. Social media has today become one of the greatest marketplaces for products and service providers in promoting their brands. This study has developed a conceptual framework in order to identify how video advertisements influence the impulsive buying behavior of consumers. The model has been tested empirically through the collection of quantitative primary data. The data has been collected from Indian consumers who have a Facebook account and use it frequently. Descriptive research design has been employed in this study. The collected data has been subject to statistical analysis through SPSS software. In addition to identifying the relationship between video advertisements and Impulsive buying behavior of consumers, this study also attempts to examine the role of the demographic characters of the consumers in moderating the relationship between the proposed variables. The results of the study reveal that social media video advertisements influence the cognitive and affective aspects of impulsive buying behavior of consumers. Further the results revealed that the relationship between social media video advertisements and impulsive buying behavior of consumers is moderated by the demographic characteristics namely age, gender and social status of the consumers.
\end{abstract}

Keywords: Impulsive Buying Behavior, Facebook, Social Media Video Advertisements

\section{INTRODUCTION}

In the recent times social media has become a predominant tool in influencing the buying behavior of consumers. Specifically, it has transformed customers' thinking pattern to a great extent (Mir and Zaheer, 2012). Social media acts as a common platform for individuals globally to connect with each other and provide data as well as experiences related to issues, activities and products (Heinrichs et al, 2011). People are influenced by fast growth of social media like Facebook, twitter and so on and as a result, firms are actively adopting them as advertising partner as well as activities of building brand (Georgios and Sergios, 2014). It permits firms to communicate with consumers with rapid reach using richer media. Such interactive way of communication among consumers permits to share and exchange data from the advertisers side as well as from consumers' side. Firms have the chance to change association with consumers from dialog to trialogue, whereas consumers contribute in remarkable association with firms and one another (Lipsman et al, 2012). With the help of social media firms had potential to build links with new and existing consumers and shape communities which interactively work together for identifying issues and developing solutions for them.

Seung (2012) identified that businesses adopt Facebook for building discussion associations with their loyal consumers, encourage their consumers to shop online as well as depend on their consumers for assisting to promote the brand through their involvement to Facebook and page given for brand. Some ad types are adopted in Facebook for obtaining high profit namely Facebook power editor, partner categories and more. Buying behavior of customer is integration of decisions, choices and perspectives while purchasing a product (Perera and Sutha, 2018). Factors influence the consumers buying behaviour are social factors like family, reference group, status and role, culture factors like social stratum, subculture, culture, personal factors namely career, age, life style, economic status, career and self- 
concept and psychological factors like attitude, belief, sensory, motivation and learning (Satrianaa, 2014).

Traditional medium for media communication was believed to be more vital for past few years whereas in recent year's social media has become significant communication mode in advertising and marketing to build brand sustainability. Social marketers communicate and interact effectively and economical to consumers by adopting the mechanism of channels in the social or digital media. Because of popularity and growth of such media, marketers are giving data and campaigns for advertisement to their consumers by adopting digital innovation (Moreno et al, 2017). With the growth of novel channels in social media the conventional electronic and print media such as newspapers, magazines, television, billboards, hoardings are facing difficulties. With the introduction of new media for interaction has developed novel chances for advertising scopes for marketers and business. Social media plays a vital role in marketing and advertising the products which highly influence consumers to buy products (Seung, 2012). Thus, this particular research intends to concentrate on examining in detail about role of Facebook video advertisements in influencing the impulsive buying behavior of consumers.

Following are the questions to be answered in this research: What are the various aspects related to impulsive buying behavior of consumers? How to develop a model for examining the role of Facebook video advertisements in influencing the impulsive buying behavior of consumers? What are strategies to be adopted for enhancing role of Facebook video advertisements in influencing the impulsive buying behavior of consumers? Aim of the research is to examine about role of Facebook video advertisements in influencing the impulsive buying behavior of consumers.

There are also researchers and studies which focus on impulsive buying behaviour of customers (Abbasi, 2017, Ahmad et al, 2019, Akram et al, 2018, Al-Zyoud, 2018, Amos et al, 2014, Badgaiyan and Verma, 2014, Farid and Ali, 2018 and Chen et al, 2019). Authors also focused on effect on social media marketing on impulsive buying behaviour in online platform (Bansal and Kumar, 2018 and Chuah and Gan, 2015). Das et al (2018) studied about effect of socioeconomic makeup of users in facebook on purchasing behaviour. Apart from these Dinesh and Bhoopathy (2019) examined about factors that influence impulsive buying behaviour with respect to Millennial consumers with respect to online platforms. Additionally, Handayani (2019) carried out a research to study about link between browsing of the product on shopping motivation and Instagram and its impacts on purchase intention. There are no studies and researchers that focused on role of facebook video advertisements in influencing the impulsive buying behaviour of consumers with cognitive and affective aspects as well as focus on demographic variables. Therefore this particular research attempts to bridge that gap by exploring role of facebook video advertisements in influencing the impulsive buying behaviour of consumers with cognitive and affective aspects as well as focus on demographic variables like age, gender, social status and family size

\section{LITERATURE REVIEW}

\section{Social media}

Social media assists people to sustain their existing links with family, friends and relatives and communicate with them with rapidity and ease. Functions of social media are categorized in different method with particular function. Social media allows the companies to directly interact with their consumers. Such strategy allows the customers to feel comfortable than conventional methods of advertising and selling. It allows the people to post comments on goods and share information (Hajli, 2014). When message is passed by different people of social media it becomes viral and reaches huge population of people. It assists marketers to know about their consumers by knowing their dislikes and like.

It assists different companies for understanding how various kinds of activities are performed. It maximizes awareness for customers how to adapt branded services and products. Social platforms assist to help existing customers and also attract new customers (Zembik, 2014). Social media marketing could be adopted in different levels namely organizational level, intraorganizational level and individual and community level. It was clear that these levels 
effectiveness relies on co-ordination of few factors, health care sectors, governments and policy makers that are efficient and act as basis for campaign of coherent communication (Hristodoulakis et al, 2015 and Bhattacharyya and Roy, 2016).

\section{Introduction to Impulsive Buying Behavior:} Choudhary (2014) refers impulsive buying as acquisition or buying of products on impulse rather than from premeditation. Impulsive buying is also known as unplanned decisions to buy any merchandise or service. Impulsive buying is an unplanned shopping performed in reaction to an external trigger. Impulse purchasing emerged upon exposure or by viewing the product to a well-planned promotional message which may be impacted by traits faced by environmental or internal states of customers.

The internal states and environmental cues perform better to trigger the impulse of customers to buy. Lu and $\mathrm{Su}$ (2018) has mentioned that the behaviour that occurs due to buying impulse resulted from product attraction which is hasty, not planned, irrational and thoughtless buying behavior is referred as impulse buying behaviour. It is the buying behavior much of emotions rather than irresistible drives and rationality. Farid and Ali (2018) has stated that impulse buying behavior is an appealing perspective of customer behavior for firms because customers end up purchasing greater than what they have actually planned for. Impulsive buying behavior is becoming the latest trend in nowadays world.

Singh and Tandon (2016) have stated that impulse purchasing behavior is a spontaneous or unplanned buying. One who intends to make such buying is known as impulse buyer. Vasanthi and Deepa (2016) defined impulse buying as a spontaneous or unplanned buying. Impulse items can be a new sample, products or well-established goods at surprisingly reduced costs. Customers who have no preplanning to buy a product have to view the product and decide to purchase the product. Thomas et al (2018) in their study has defined impulse buying as an immediate and sudden buying with no pre-shopping intentions either to purchase the particular category of product or to satisfy a specific purchasing task. Impulse buying behavior exists after facing an urge to purchase and intends to be spontaneous without several reflections.

Similarly, Mainali et al (2016) has stated that impulse purchasing is an instantaneous and spontaneous buying where the customer is not involved actively in search of a good and has no appropriate pre-mindset to buy. Impulse buying is much emotional than rational. Thompson and Prendergast (2015) have stated that impulsive buying is a spontaneous buying or taking product ownership without any deep thinking. People who are highly involved with impulse purchasing are the ones who get connected emotionally to product easily and are the ones who tend to be fulfilled with on the spot product. Ozer and Gultekin (2015) has mentioned that people who have positive mood are probable to chose for impulse purchasing and tend to be much excited about online shopping compared to negative mood people.

Impact of Social Media Video Advertisement on Impulse Buying Behavior of consumers: Bansal and Kumar (2018) proposed a study on the social media marketing role and their effect on impulsive buying behaviour. Unplanned buying enhances due to marketing of social media and additional expenses due to factors of social media. Similarly, in Al-Zyoud (2018) study the factors influencing social media are hedonic motivation, trust, website quality and variety seeking. The results of Akram et al (2018) ensure positive impact of situational factors on online impulse purchase among the online shoppers in social commerce surroundings. Chen et al (2019) study results urge to purchase impulsively is decided by affective trust in recommender and affection towards the suggested product which are impacted by both recommender and product related signals.

The study of Sharma, Mishra and Arora (2018) examines the impact of social media advertisement and social media community on impulse purchase intention. The study shows essential relationship among different factors that impact impulse buying behaviour of consumers with indices of adequate model fit. Chitharanjan (2016) has found in their study that if business requires impacting the customer behaviour towards their services 
and products, they have to undertake their ads using channels of social media.

Kazi et al (2018) studied the impact of social media on impulse purchasing behaviour of consumers and also examined the essential factors influencing impulsive purchasing behaviour of consumers. The results of the study showed that social media have essential and positive effect on consumer's impulse purchasing behavior. Husnain et al (2016) found in their study that online social communication can strongly develop the buying behavior of customers on impulse when individual shows the traits. Similarly, in the research of Wahab et al (2018) the motivation of online buying on hedonic motivation has essential impact on impulsive purchasing and browsing of products. Shafique et al (2015) has mentioned in their research that trust plays an essential part on the buying decision of online and offline impulse buying.

Kumar and Kaur (2018) investigated the factors influencing the online impulsive buying behavior of customers. The possibility of customers to purchase impulsively is recommended to enhance further because of online shopping convenience. The outcomes of the research will be useful for online organizations which need to enhance the online impulse purchasing behavior of customers. Similarly, Badgaiyan and Verma (2014) examined the impact of personality, materialism, culture, tendency of shopping enjoyment and impulsive purchasing tendency on impulsive purchasing behavior. Chuah and Gan (2015) examined whether the emotions, hedonic motivation and personality impact impulse purchasing behavior when shopping through internet. Ahmad et al (2019) has mentioned in their study that consumers have greater self-esteem level which tends to imagine twice before buying anything as they are confident about their personality and decisions.

The study of Handayani (2019) determines how hedonic motivation and utilitarian motivation impact buying intention, impulse purchasing, intention of word of mouth and how social media browsing of information impact on hedonic and utilitarian motivation. Based on the outcome the attitude of searching beauty products has a positive impact on buying motivation. Utilitarian motivation has a positive impact on buying intention but does not have a positive impact of impulse purchasing and WOM intention.

Conversely hedonic motivation has a positive impact on WOM intention, impulse buying and buying intention. In the study of Sebayang et al (2019) hedonic motivation has an essential impact on impulse buying. Similarly, Yu et al (2018) has mentioned that hedonic shopping values are impacted by construct of entertainment and utilitarian values of shopping are positively associated to selection, convenience and monetary saving. Lo et al (2016) has stated that sales promotion stimuli facilitate online impulse buying effectively and provides hedonic or utilitarian advantage to customers.

Kathiravan et al (2019) has mentioned in their study that the buying behavior understanding of online consumers as far as their impulsive conduct would be helpful for academicians and advertisers.

The main purpose of this study is to consider a gender at components which strives for internet shopping and to construct a comprehension of variables influencing internet shopping by customers. Kumar and Narayanan (2016) study determines the shoppers impulse buying behavior at clothing multi brand shops using retail categories and socio-economic factors. Similarly, the study of Das et al (2018) aims to set up whether the Facebook users' socio-economic factors has a different impact on their purchasing decisions after exposing to advertisements on it.

Zhou and Gu (2015) has stated that shopping circumstances and personal qualities influence option of customer impulse purchasing behaviour during promotion of sales. When implementing a reduction of cost, retailers tend to favour one practice over the other yet, how varied implementations of a cost promotion impact impulse purchasing behaviour of customer has been learnt inadequately. This study framed a reduction of cost in the money amount versus products percentage to examine how the expected regret impacts likelihood to impulse purchasing. The study of Huang and Esterhammer (2017) found which factors contribute to the regret feeling during impulse buying. Tang and Hao (2017) predicted that promotion of price will essentially impact 
impulsive purchasing behaviour of customer and utility of transaction had a partial mediating impact between impulsive purchasing and promotion of price.

Triwidisari et al (2017) determined the impact of using Instagram social network and motives of hedonic shopping to impulse purchasing media and to know whether financial literacy is capable to moderate the impact of Instagram social network use and motives of hedonic shopping to impulse purchasing. The motives of hedonic shopping and Instagram social media usage have significant and positive impact to impulse purchasing behavior of students. Financial literacy moderate the impact of Instagram social media use to impulse purchasing while not able to moderate the impact of hedonic shopping motives on impulse purchasing. Ustanti (2018) had mentioned in their research that hedonic shopping essentially impact on impulse purchasing behavior of middle class society in internet shopping. Lins et al (2014) has stated in their research that hedonic shopping is positively associated to impulse buying tendency.

Ling and Yazdanifard (2015) studied the online impulsive purchasing behavior causes which are essential as such research may produce some creative strategies or notions to marketers to enhance profit from online market. In this research the authors uses external and internal factors in studying the impulsive purchasing behavior. The internal factors and external factors which cause impulsive buying are interrelated in some perspectives and are difficult to isolate individually. Sahai et al (2019) has stated that a positive correlation was viewed between psychological perception of customers and their desire to purchase online. Fioretti (2018) examined the internal factors, product category and situational factors within customers than can influence impulse purchase. Amos et al (2014) viewed at the effect of outside events or situations on impulse buying and predicted that positive social impact can enhance impulse purchasing. Khorrami and Esfidani (2015)identified the impact of situational factors on compulsive buying and impulsive buying.

Dinesh and Bhoopathy (2019) have mentioned in their research that marketers are viewing into the behavior to enhance the online sales. Number of users influencing and/or accompanying during impulse buying and huge amount of income at the initial stage of moth are certain factors that impact impulsive purchasing behavior though the effect is not that essential marketers must view into quantifying variables using big data to perceive the factors better. Singh (2018) has mentioned in their research that high-income group involve in much impulse purchasing than low income group. Luniya and Varghese (2015) have mentioned in their study that impulse buying behaviour of people increases with the increase in their income.

The below table shows the impact of social video advertising in influencing the impulsive buying behaviour of consumers:

Table 1: Content Analysis

\begin{tabular}{|l|l|l|l|}
\hline S.No. & Author \& Year & $\begin{array}{l}\text { Social media factors } \\
\text { influencing impulsive } \\
\text { buying behavior }\end{array}$ & Findings of the research \\
\hline 1 & $\begin{array}{l}\text { Bansal and Kumar2018; } \\
\text { Alzyoud, 2018; Kazempour } \\
\text { and Lotfizadeh, 2017; Chen } \\
\text { et al, 2019 }\end{array}$ & $\begin{array}{l}\text { Hedonic motivation, quality } \\
\text { of website, ethical and trust } \\
\text { values, variety seeking and } \\
\text { situational variable }\end{array}$ & $\begin{array}{l}\text { Unplanned buying enhances } \\
\text { due to marketing of social } \\
\text { media and additional expenses } \\
\text { due to factors of social media }\end{array}$ \\
\hline 2 & $\begin{array}{l}\text { Sharma, Mishra and Arora, } \\
2018 ; \text { Chitharanjan, 2016; }\end{array}$ & $\begin{array}{l}\text { Social media community } \\
\text { and social media } \\
\text { advertisement }\end{array}$ & $\begin{array}{l}\text { Positive impact of social media } \\
\text { advertisement and social } \\
\text { media community on impulse } \\
\text { buying intention }\end{array}$ \\
\hline 3 & $\begin{array}{l}\text { Kazi et al, 2019; Husnain et } \\
\text { al, 2016; Wahab et al, 2018; } \\
\text { Shafique et al, 2015 }\end{array}$ & $\begin{array}{l}\text { Social Network Marketing, } \\
\text { Hedonic Motivation, Trust, } \\
\text { electronic WoM and } \\
\text { impulsive purchasing }\end{array}$ & $\begin{array}{l}\text { Online marketers and retailers } \\
\text { must perceive the significance } \\
\text { of social media for motivating } \\
\text { online consumers impulsive }\end{array}$ \\
\hline
\end{tabular}




\begin{tabular}{|c|c|c|c|}
\hline S.No. & Author \& Year & $\begin{array}{l}\text { Social media factors } \\
\begin{array}{l}\text { influencing impulsive } \\
\text { buying behavior }\end{array}\end{array}$ & Findings of the research \\
\hline & & behavior & purchasing. \\
\hline 4 & $\begin{array}{l}\text { Kumar and Kaur, 2018; } \\
\text { Badgaiyan and Verma, 2014; } \\
\text { Chuah and Gan, 2015; } \\
\text { Ahmad et al, } 2019\end{array}$ & $\begin{array}{l}\text { Personal Behaviour, } \\
\text { circumstance at the time of } \\
\text { buying, ethical problems } \\
\text { and promotion }\end{array}$ & $\begin{array}{l}\text { Huge advantage to electronic } \\
\text { marketers in devising schemes } \\
\text { through which they can } \\
\text { stimulate customers impulse } \\
\text { buying behaviour and enhance } \\
\text { the products sales }\end{array}$ \\
\hline 5 & $\begin{array}{l}\text { Handayani, 2019; } \\
\text { Sebayang et al, 2019; Yu et al, } \\
\text { 2018; Lo et al, } 2016\end{array}$ & $\begin{array}{l}\text { Utilitarian motivation and } \\
\text { Hedonic Motivation }\end{array}$ & $\begin{array}{l}\text { Utilitarian motivation has a } \\
\text { positive impact on buying } \\
\text { intention and conversely } \\
\text { hedonic motivation has a } \\
\text { positive impact on WOM } \\
\text { intention, impulse buying and } \\
\text { buying intention }\end{array}$ \\
\hline 6 & $\begin{array}{l}\text { Kathiravan et al, 2019; } \\
\text { Kumar and Narayanan, 2015; } \\
\text { Das et al, 2018; }\end{array}$ & Socio-economic factors & $\begin{array}{l}\text { Critical link between } \\
\text { supposition of customers } \\
\text { about unconstrained } \\
\text { purchasing satisfy customers } \\
\text { to shop impulsively }\end{array}$ \\
\hline 7 & $\begin{array}{l}\text { Zhou and Gu, 2015; Huang } \\
\text { and Esterhammer, 2017; } \\
\text { Tang and Hao, 2017; }\end{array}$ & $\begin{array}{l}\text { Promotion of price and } \\
\text { Anticipated Regret }\end{array}$ & $\begin{array}{l}\text { Presentation of price has an } \\
\text { essential effect on customer } \\
\text { impulse purchasing behaviour } \\
\text { and anticipated regret } \\
\text { influences the effect of varied } \\
\text { presentation promotion on } \\
\text { impulse purchasing behaviour } \\
\text { of customers }\end{array}$ \\
\hline 8 & $\begin{array}{l}\text { Triwidisari et al, 2017; } \\
\text { Ustanti, 2018; Lins et al, } 2014\end{array}$ & $\begin{array}{l}\text { Social media usage, Motives } \\
\text { of hedonic shopping and } \\
\text { Financial literacy }\end{array}$ & $\begin{array}{l}\text { Motives of hedonic shopping } \\
\text { and social media usage of } \\
\text { Instagram have significant and } \\
\text { positive effect to impulse } \\
\text { purchasing of students }\end{array}$ \\
\hline 9 & $\begin{array}{l}\text { Lim and Yazdanifard, 2015; } \\
\text { Sahai et al, 2019; Fioretti, } \\
\text { 2018; Amos et al, 2014; }\end{array}$ & $\begin{array}{l}\text { Internal Factors, } \\
\text { Psychological factors, } \\
\text { Situational Factors, } \\
\text { Characteristics of Product } \\
\text { and Website Characteristics }\end{array}$ & $\begin{array}{l}\text { Online impulsive purchasing } \\
\text { behaviour is essential in } \\
\text { enhancing returns to sellers } \\
\text { and experience of shopping to } \\
\text { customers }\end{array}$ \\
\hline 10 & $\begin{array}{l}\text { Dinesh and Bhoopathy, 2019; } \\
\text { Singh, 2018; } \\
\text { Luniya and Varghese, } 2015\end{array}$ & $\begin{array}{l}\text { Number of users } \\
\text { influencing and huge } \\
\text { amount of income }\end{array}$ & $\begin{array}{l}\text { Frequency of buying an online } \\
\text { product shows better chances } \\
\text { so that marketers could use by } \\
\text { enhancing campaigns and } \\
\text { advertisements to these } \\
\text { demographic characteristics to } \\
\text { expand the buying importance } \\
\text { of customers }\end{array}$ \\
\hline
\end{tabular}

Source: Author's observations 


\section{Conceptual Framework}

The following figure illustrates the conceptual framework for the role of Facebook video advertisements in influencing the impulsive buying behavior of consumers

\begin{tabular}{|cl|}
\hline M: Demographic characteristics \\
- & Age \\
$\bullet$ & Gender \\
$\bullet$ & Social Status \\
$\bullet$ & Family size \\
\hline
\end{tabular}

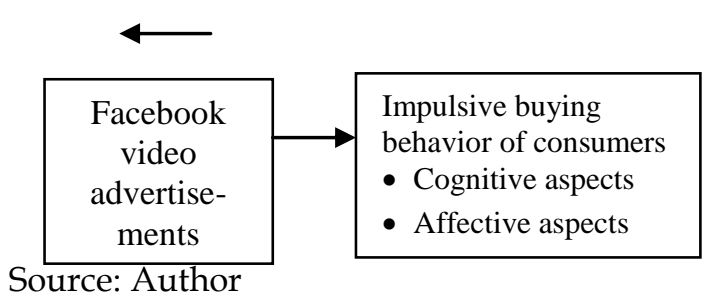

Figure 1: The conceptual framework for the role of Facebook video advertisements in influencing the impulsive buying behavior of consumers

\section{Hypothesis:}

- Null Hypothesis: The role of Facebook video advertisements does not influence the cognitive aspects of impulsive buying behavior of consumers

Alternative Hypothesis: The role of Facebook video advertisements influences the cognitive aspects of impulsive buying behavior of consumers

- Null Hypothesis: The role of Facebook video advertisements does not influence the affective aspects of impulsive buying behavior of consumers

Alternative Hypothesis: The role of Facebook video advertisements influences the affective aspects of impulsive buying behavior of consumers

- Null Hypothesis: The relationship between Facebook video advertisements and impulsive buying behavior of consumers is not moderated by the demographic characteristics

Alternative Hypothesis: The relationship between Facebook video advertisements and impulsive buying behavior of consumers is moderated by the demographic characteristics
$>$ The relationship between Facebook video advertisements and impulsive buying behavior of consumers is moderated by age

> The relationship between Facebook video advertisements and impulsive buying behavior of consumers is moderated by gender

> The relationship between Facebook video advertisements and impulsive buying behavior of consumers is moderated by social status

> The relationship between Facebook video advertisements and impulsive buying behavior of consumers is moderated by family size

\begin{tabular}{|c|c|c|c|}
\hline $\begin{array}{l}\text { S. } \\
\text { No }\end{array}$ & $\begin{array}{l}\text { Author } \\
\text { and Year }\end{array}$ & $\begin{array}{c}\text { Variable } \\
\mathrm{s}\end{array}$ & Definition \\
\hline 1 & $\begin{array}{c}\text { Rook and } \\
\text { Hoch, } 1985\end{array}$ & $\begin{array}{l}\text { Cognitive } \\
\text { aspects }\end{array}$ & $\begin{array}{l}\text { Customers indicate } \\
\text { various attitudes in } \\
\text { various circumstances } \\
\text { and indicate various } \\
\text { pattern for } \\
\text { consumption with } \\
\text { specific reference to } \\
\text { products involvement. } \\
\text { Products with low } \\
\text { involvement have } \\
\text { unique impact on } \\
\text { consumption pattern } \\
\text { of people instead of } \\
\text { products with high } \\
\text { involvement }\end{array}$ \\
\hline 2 & $\begin{array}{c}\text { Coley and } \\
\text { Burgess, } \\
2003\end{array}$ & $\begin{array}{l}\text { Affective } \\
\text { aspects }\end{array}$ & $\begin{array}{l}\text { It is related to moods, } \\
\text { feelings and emotions. } \\
\text { Consumption of } \\
\text { products is processed } \\
\text { when a customer feel } \\
\text { variance in their actual } \\
\text { being state and desired } \\
\text { one. }\end{array}$ \\
\hline 3 & $\begin{array}{c}\text { Hoch and } \\
\text { Loewenstei } \\
\text { n, } 1991\end{array}$ & $\begin{array}{l}\text { Impulse } \\
\text { buying } \\
\text { behavior }\end{array}$ & $\begin{array}{l}\text { Open buying of } \\
\text { products by peoples } \\
\text { without explicit } \\
\text { intentions to buy or } \\
\text { prior planning is very } \\
\text { significant for } \\
\text { companies. }\end{array}$ \\
\hline
\end{tabular}

\section{RESEARCH METHODOLOGY}

Paradigms of the research are categorized into different types namely interpretivism, positivism, pragmatism, critical paradigms, 
subjectivism (Patel, 2015). In this study, investigator adopts the positivist paradigm, since the proposed work examined the role of Facebook video advertisements in influencing the impulsive buying behavior of consumers. Positivism paradigm was adopted since this research analyzes the quantitative way of approach. Positivist paradigm has tools to gauge the events, facts and information. Design of the research helps investigator to make research effectively by giving more amount of information with lesser quantity of effort, time and money. This research makes use of descriptive research as the design of the research. This research numerically tests the role of Facebook video advertisements in influencing the impulsive buying behavior of consumer. The sampling methodology is generally adopted by investigator to choose desired samples of study. Sampling methods are mostly probability sampling and nonprobability sampling methods. This particular research makes use of simple random sampling methods. Each respondent are selected randomly that is they are selected by a chance and it is also named as probability sampling.

The sample size of the study for quantitative approach of the research is 324 consumers. The target population is the group of respondents chosen by the investigator to carry out the investigation to gather primary data. In this research, the selected respondents are consumers to study about their impulsive buying behavior in social media.

Data for this research could be gathered in 2 ways namely secondary and primary data. Primary information of the research are directly gathered from respondents where as the secondary type of data are gathered from prior resources. In this research, survey methods were used for collecting the primary data. In this research, investigator would give closed end questionnaires to collect data from the selected participants. Investigators would give closed ended questionnaires to 324 consumers. Secondary data are collected from external materials such as journals, research papers, internet, articles, and books which are related to research namely role of Facebook or social media video advertisement which influence impulsive buying behavior of the consumers. After acquiring primary data from the respondents, graphical or statistical kind of tools are adopted for analyzing the collected primary data. Hypotheses of the research are tested with the help of Karl Pearson correlation test. Software tools adopted are Microsoft excel and SPSS. Investigator has followed proper and accurate practice for carrying out the research. Information gathered for this research is to be adopted only for academic and research purposes only. In this research, ethics is strictly maintained and followed by the investigator to promise the consumers to keep their answers very secure.

\section{ANALYSIS}

This section explains about the analysis of data to measure the role of Facebook video advertisements in influencing the impulsive buying behavior of consumers. This section also describes about statistical techniques adopted in this research namely regression, factor analysis and correlation test.

\section{Reliability}

Below table explains about reliability of the constructs. Alpha value for cognitive aspects is 0.922. Alpha value for affective aspects is 0.947 .

Table 2: Reliability analysis

\begin{tabular}{|l|l|l|l|}
\hline S.No & \multicolumn{1}{|c|}{ Construct } & Items & Alpha \\
\hline 1 & Cognitive Aspects & 10 & .922 \\
\hline 2 & Affective Aspects & 10 & .947 \\
\hline
\end{tabular}

Below table explains total variance explained for all components of cognitive and affective aspects. Eigen values for component in cognitive aspects are 1, 2, 3, 4 are 9.302, 3.582, 1.356 and 1.051 respectively. Eigen values for component in affective aspects are 15, 16, 17, 18,19 and 20 are 3.119E-0.16, 1.612E-016, 3.804E-018, 4.358E-017 and 1.943E-016 respectively. 
Table 2: Factor analysis- Variance table

Total Variance Explained

\begin{tabular}{|c|c|c|c|c|c|c|c|c|c|}
\hline \multirow{2}{*}{ 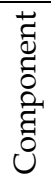 } & \multicolumn{3}{|c|}{ Initial Eigen Values } & \multicolumn{3}{|c|}{$\begin{array}{l}\text { Extraction Sums of Squared } \\
\text { Loadings }\end{array}$} & \multicolumn{3}{|c|}{$\begin{array}{c}\text { Rotation Sums of Squared } \\
\text { Loadings }\end{array}$} \\
\hline & Total & $\begin{array}{c}\% \text { of } \\
\text { Variance }\end{array}$ & $\begin{array}{c}\text { Cumulative } \\
\%\end{array}$ & Total & $\begin{array}{c}\text { \% of } \\
\text { Variance }\end{array}$ & $\begin{array}{c}\text { Cumulative } \\
\%\end{array}$ & Total & $\begin{array}{c}\% \text { of } \\
\text { Variance } \\
\end{array}$ & $\begin{array}{c}\text { Cumulative } \\
\%\end{array}$ \\
\hline 1 & 9.302 & 46.512 & 46.512 & 9.302 & 46.512 & 46.512 & 6.847 & 34.233 & 34.233 \\
\hline 2 & 3.582 & 17.912 & 64.423 & 3.582 & 17.912 & 64.423 & 6.038 & 30.190 & 64.423 \\
\hline 3 & 1.356 & 6.779 & 71.203 & & & & & & \\
\hline 4 & 1.051 & 5.253 & 76.456 & & & & & & \\
\hline 5 & .922 & 4.609 & 81.065 & & & & & & \\
\hline 6 & .651 & 3.255 & 84.320 & & & & & & \\
\hline 7 & .578 & 2.890 & 87.209 & & & & & & \\
\hline 8 & .479 & 2.395 & 89.604 & & & & & & \\
\hline 9 & .451 & 2.254 & 91.858 & & & & & & \\
\hline 10 & .434 & 2.169 & 94.026 & & & & & & \\
\hline 11 & .378 & 1.890 & 95.916 & & & & & & \\
\hline 12 & .319 & 1.595 & 97.511 & & & & & & \\
\hline 13 & .253 & 1.263 & 98.775 & & & & & & \\
\hline 14 & .245 & 1.225 & 100.000 & & & & & & \\
\hline 15 & 3.119E-016 & $1.560 \mathrm{E}-015$ & 100.000 & & & & & & \\
\hline 16 & 1.612E-016 & 8.059E-016 & 100.000 & & & & & & \\
\hline 17 & $-3.804 \mathrm{E}-018$ & -1.902E-017 & 100.000 & & & & & & \\
\hline 18 & $-4.358 \mathrm{E}-017$ & $-2.179 \mathrm{E}-016$ & 100.000 & & & & & & \\
\hline 19 & $-4.823 \mathrm{E}-017$ & $-2.412 \mathrm{E}-016$ & 100.000 & & & & & & \\
\hline 20 & $-1.943 \mathrm{E}-016$ & $-9.716 \mathrm{E}-016$ & 100.000 & & & & & & \\
\hline
\end{tabular}

Below table explains about component transformation matrix for cognitive aspect and affective aspect with respect to impulsive buying behaviour.

Table 3: Factor analysis- Component transformation matrix

Component Transformation Matrix

\begin{tabular}{|l|r|r|}
\hline Component & 1 & 2 \\
\hline 1 & .755 & .655 \\
\hline 2 & -.655 & .755 \\
\hline
\end{tabular}

Extraction Method: Principal Component Analysis.

Rotation Method: Varimax with Kaiser Normalization.

In the regression analysis model summary, the $R$ value is found to be $.634, R^{2}$ value is found to be .402 and adjusted $R^{2}$ square value is found to be .401. It is found to be the value of .402 that our independent variable explains $40.2 \%$ of the dependent variable. From the anova table, it was clear that value is significant.

Below table explains about coefficients and residuals statistics.

Table 4: Coefficients

Coefficients $^{a}$

\begin{tabular}{|c|c|c|c|c|c|c|}
\hline \multirow{2}{*}{ Model } & \multicolumn{2}{|c|}{$\begin{array}{c}\text { Unstandardized } \\
\text { Coefficients }\end{array}$} & $\begin{array}{c}\text { Standardized } \\
\text { Coefficients }\end{array}$ & \multirow{2}{*}{$\mathrm{t}$} & \multirow{2}{*}{ Sig. } \\
\cline { 2 - 5 } & $\mathrm{B}$ & $\begin{array}{c}\text { Std. } \\
\text { Error }\end{array}$ & Beta & & \\
\hline \multirow{2}{*}{1} & (Constant) & .349 & .221 & & 1.576 & .116 \\
\cline { 2 - 6 } & MEAN & .971 & .066 & .634 & 14.705 & .000 \\
\hline
\end{tabular}

a. Dependent Variable: FRE

\section{Source: Primary data}




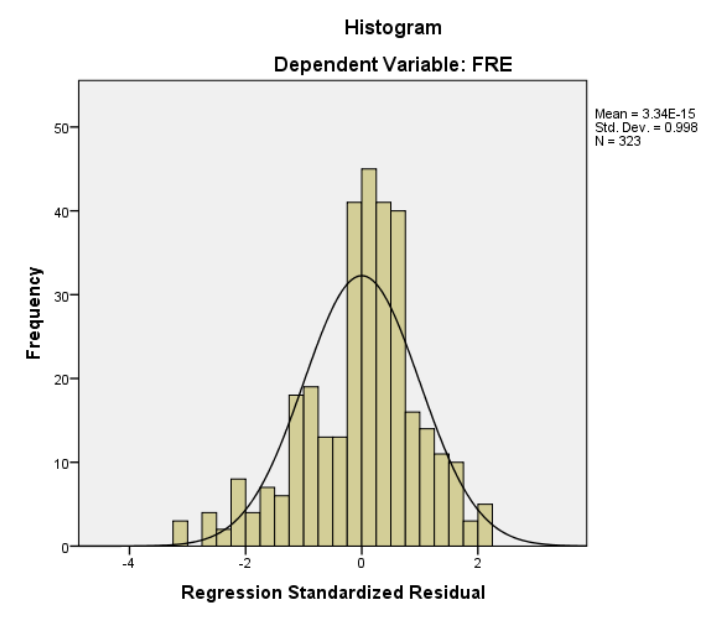

Figure 2: Histogram

Source: Primary data

This chart explains about regression standardized residual.

Discussion, managerial implications and limitations of the study:

The current papermakes an effort to identify that there is a strong association between the attractiveness factors of social media particularly Facebook advertising with impulsive buying behavior processes. The findings of the test of hypothesis is summarized below:

Table 10: Findings of the Test of Hypothesis

\begin{tabular}{|l|l|l|}
\hline $\begin{array}{c}\text { S. } \\
\text { No }\end{array}$ & \multicolumn{1}{|c|}{ Hypothesis } & $\begin{array}{l}\text { Accepted/ } \\
\text { Rejected }\end{array}$ \\
\hline 1 & $\begin{array}{l}\text { There is a relationship } \\
\text { between the Facebook, } \\
\text { social media } \\
\text { advertisement and } \\
\text { impulsive buying } \\
\text { behaviour }\end{array}$ & Accepted \\
\hline 2 & $\begin{array}{l}\text { Family size moderates the } \\
\text { relationship between the } \\
\text { Facebook, social media } \\
\text { advertisement and } \\
\text { impulsive buying } \\
\text { behaviour }\end{array}$ & Accepted \\
\hline 3 & $\begin{array}{l}\text { Social status moderates } \\
\text { the relationship between } \\
\text { the Facebook, social } \\
\text { media advertisement and } \\
\text { impulsive buying } \\
\text { behaviour }\end{array}$ & Accepted \\
\hline
\end{tabular}

Role of Facebook advertisement in impulsive buying behavior

Businesses are changing their marketing techniques and practices towards social media for advertising their products and services. Of these, video advertisements are one of the thriving platforms of social-media marketing (Niazi, et al 2012). As a consumer, employing online medium for several reasons in daily life has become quite normal. Marketers are as well accepting this change and implementing required activities in advertising and promotional strategies. The main goal of company/organization is to get through to potential consumers and creates influence on their purchasing behavior (Ayanwale et al., 2005). According to Adelaar et al. (2003) purchasing behavior is generated by emotional response factors, which include pleasure, arousal and excitement. Accordingly in social media video advertisement, the three abovementioned factors are influencing the purchasing behavior of customers (Niazi, et al 2012) and also emphasized that one of the important reasons of the social media marketing continues to develop is that contrary to other channels of advertising, it brings an opportunity to companies to promote their products \& services in a variety of formats tailored to their resources and demands.

Customers who spend a lot of time, effort and money into a buying process might face cognitive element on whether a perfect choice has been made (Kotler and Armstrong, 2014). This makes the customer look for loyal information to lessen the difference, by either confidently authorizing the decision made, or determining that it has been a reckless decision. When the question was asked to respondents whether social media video advertisement influences their purchasing behavior, the majority of respondents reported sometimes and others posited yes and hardly a few respondents said yes. In the current study, respondents were asked to rate their perception in terms of cognitive and affective aspects as well. $43 \%$ of respondents disagreed to the point that they think carefully before they buy something. Similarly, the mediating impacts of internal state of both affective and cognitive-based aspects for the impact of stimuli and the buying intention are exhibited in various experiential studies (Chang and Chen, 2008). Regardless of the recognition of 
the cognitive aspects, customers do not always act so sensibly throughout their consumption activities; moderately, their satisfaction as well is based on a sequence of affective experiences which are partially intuitive and automatically created, and do not necessitate complete information processing. The online streamvideo commercials are developing as the most important category of online advertisements. YouTube's True-View in-stream video commercials seem to have been successful in considerably lessening the negative user influences of online advertising without negotiating the value of such commercials to advertisers (Pashkevich et al., 2012). Comparatively, online video advertisements give the advanced level of brand/product recall and congeniality than that of $\mathrm{TV}$ commercials. Intrusiveness can be considered as the core of potentially inimical advertising effects. Besides, intrusiveness would have major destructive effects on attitude and buying intention. In the online platform, on account of customers' greater goal-related focus (Goodrich, et al 2015), longer video ads will hold a customer off from his or her aspiration for a longer period, possibly intensifying feelings of intrusiveness and optimistic behaviors toward the ads.

\section{Relationship between income and affective and cognitive aspects}

Remarkable growths in individual disposable incomes and access to credit have made impulsive buying in retail contexts. Vohs and Faber, (2007) emphasized that the characteristics of customers and their demographics factors particularly income impact the impulse purchasing. From a socioeconomic perspective, people with comparatively low levels of income are likely to take pleasure in immediate indulgence as against delay-of-satisfaction (Muruganantham and Bhakat 2013) and also emphasized that increased income, lifestyle and easy access to credit have made impulse buying an extensive occurrence across the various retail systems. Only $37 \%$ of the respondents agreed that their most of their purchases are planned in advance and $27 \%$ of the respondents agreed the term. Most of the consumers make the purchase eventually once they seen the online video advertisement (Alijani et al., 2010). Also, it has been emphasized that subjective variables, such as entertainment and information, has a positive effect on behavior towards online video commercials (Lee et al., 2011). According to (Taylor, et al 2011) video advertising in social media has the positive impact on the purchasing intention of consumers. The findings of the study emphasized that income acts as a moderator on the relationship between affective and cognitive aspects.

\section{Managerial implications}

This study has given the academicians, practitioners, marketers with knowledge about online shopping behavior from customer's perspective. Although this study's concentrate were mainly on role of facebook video advertisements in influencing the impulsive buying behavior of consumers, investigator have profoundly focused into cognitive and affective aspects and how they influence consumers through facebook advertisements. This research provides valuable information to companies; marketers like to involve their market inside the platforms of social media. At the same time, this research concentrates on business to customer commercial activities like specialists or marketers in social media for advertising their products. Such findings are could be adopted as basis for set of principles and guidelines when adopting social networking sites more particularly facebook which found to be efficient and effective in the behavior of market.

\section{LIMITATIONS OF THE RESEARCH}

Findings of the study are restricted to Facebook video advertisements and this study has been conducted from the perspective of consumers alone. This particular research focuses on the impulsive buying behavior of consumers. Categorically, this study is limited to these demographic aspects namely family size, age, gender and social status. Thus, the outcomes acquired by carried out the survey are constrained by sample size, refer that, our outcomes are not generalized in a large scale.

\section{CONCLUSION AND FUTURE WORK}

Most common usage of facebook across the world has made it valuable and significant platform for advertising where marketers place their advertisement for reaching their valuable customers. Facebook permits businesses and marketers for targeting particular customer as well as encouraging their goods or services through efficient 
advertisement. From the findings of the research, it was clear that facebook allows the service providers, manufacturers and marketers for reaching consumers of particular group of age and interest. Responses from customers are significant for firms, marketers to influence impulsive buying behavior. Based on the expectations of customers, marketers have to develop more impact on impulsive buying behavior of customers.

The descriptions of impulsive purchasing literature were generally focused on the product whilst defining an impulse buying. The existing studies did not integrate the customer and his individual qualities as the factor impacting impulse purchases. At the time of impulse buying, the customer experiences an immediate, overwhelming and persistent desire. The research makes an effort to determine if Facebook advertising or other social media advertising is efficient in influencing the impulsive buying and purchasing intention of customers. Over the past few decades, two well-distinguished research practices could be observed, i.e. cognitive and affective. An extensive range of experience of customers' satisfaction has been developed. The current contribution experiential research carried out under these two insights to define which components are associated with buying intention, the relationships between the two major approaches. The motivation for this occurrence is to determine how to attribute an interest when it takes place, as well as and also how to handle advertisements to attract people, based on what kind of activity they wish to take place. Accordingly, this research pays attention to this call and deals with cognitive attitudes, as these have a major impact on customer behavior. The findings of the study emphasizes the complication of a model in which cognitive-affective factors are present, and improves knowledge on the effects of perceived interactivity. Substantial use of Facebook across the world has made it an effective and significant advertising platform, where companies categorize their advertisements to reach and attract their potential customers. Facebook as the platform for viewers provides information, attractive images, videos, etc. Online video advertising generally has the nature of intruding and attracting a human being at times and as well appears in between their goal-directed task and this type of interruption regarded as the perceived invasiveness. To conclude, the study accepted the hypothesis that there is a relationship between the Facebook, social media advertisement and impulsive buying behavior and as well family size and income moderates the relationship between the Facebook, social media advertisement and impulsive buying behavior.

Further this research exclusively focuses on impulsive buying behavior of consumers. The study therefore could be extended to other social media platforms. It could be examined from the marketer's perspective as well in the future in addition to conducting a qualitative data analysis as well through collection of detailed view of consumers as well as marketers on social media advertisements and their impact on impulsive buying behavior in the future.

\section{REFERENCES}

Abbasi, B. (2017). Relationship between Consumer Characteristics and Impulse Buy Behavior: The Mediating Role of Buying Intention of New Clothing Buyers. International Review of Management and Marketing, 7(1), pp 26-33.

Adelaar, T., Chang, S., Lanchndorfer, K. M., Lee B. \& Morimoto M. (2003). Effects of Media Formats on Emotions \& Impulse Buying Behavior. Journal of Information Technology, volume 18, pp. 247-266.

Ahmad, M. B., Ali, H. F., Malik, M. S., Humayun, A. A., \& Ahmad, S. (2019). Factors Affecting Impulsive Buying Behavior with mediating role of Positive Mood: An Empirical Study. European Online Journal of Natural and Social Sciences, 8(1), pp-17.

Akram, U., Hui, P., Khan, M., Yan, C., \&Akram, Z. (2018). Factors affecting online impulse buying: evidence from Chinese social commerce environment. Sustainability, 10(2), 352.

Al-Zyoud, M. F. (2018). Does social media marketing enhance impulse purchasing among female customers case study of Jordanian female shoppers. Journal of Business and Retail Management Research, 13(2).

Amos, C., Holmes, G. R., \&Keneson, W. C. (2014). A meta-analysis of consumer impulse 
buying. Journal of Retailing and Consumer Services, 21(2), pp 86-97.

Ayanwale, A. B., Alimi, T. \&Ayanbimipe, M. A. (2005). The Influence of Advertising on Consumer Brand Preference. Journal of Social Science, 10(1), pp. 9-16.

Badgaiyan A J and Verma A (2014), Intrinsic factors affecting impulsive buying behaviour-Evidence from India. Journal of Retailing and consumer services, 21(4), 537-549.

Bansal M and Kumar S K (2018), Impact of Social Media Marketing on Online Impulse Buying Behaviour, Journal of Advances and Scholarly Researches in Allied Education, Volume 15, Issue 5, pp 136-139.

Bhattacharyya.M and Roy.P (2016), Engaging social media in health communication: Scope and Challenges of the $21^{\text {st }}$ Century, Journal of content, community and communication, vol $3,38-43$.

Chen, Y., Lu, Y., Wang, B., \& Pan, Z. (2019). How do product recommendations affect impulse buying? An empirical study on WeChat social commerce. Information $\mathcal{E}$ Management, 56(2), 236-248.

Chitharanjan, A. (2016). Analysing the impact of social media marketing and online advertisements on consumer behaviour (Doctoral dissertation, Dublin Business School).

Chuah S L and Gan C C (2015), The Influence of Individual Internal Factors on Impulse Buying Behaviour through Online Shopping, Global Journal of Business and Social Science Review, Vol. 1(1) 2013. 59-69.

Coley A, Burgess B., Gender differences in cognitive and affective impulse buying, Journal of Fashion Marketing and Management, 7(3), 282-295,2003

Das S, Mondal S R, Sahoo K K, Nayyar A and Musunuru K (2018), Study on the impact of socioeconomic makeup of Facebook users on purchasing behaviour, RevistaEspacios, Volume 39, Number 33, pp 28.

Dinesh P and Bhoopathy S (2019), A Study On Factors Influencing Impulsive Buying Behavior In Millennial Consumers With Special Reference To Online Platforms, International Journal of Research and Analytical Reviews, Volume 6, Issue 1, pp 858865.
Esterhammer, O., \& Huang, J. (2017). The Triggers of Buyers Regret of Impulsive Purchases, Available at http://www.divaportal.org/smash/get/diva2:1106734/FULLT EXT01.pdf, accessed on 19th December 2019.

Farid, D. S., \& Ali, M. (2018). Effects of Personality on Impulsive Buying Behavior: Evidence from a Developing Country. Marketing and Branding Research, 5, pp 31-43.

Fioretti, T (2018), "Branding Factors that Influence Impulse Buying" (2018). Undergraduate Honors College Theses 2016-. 44.

Georgios Tsimonis\&SergiosDimitriadis, (2014). Brand strategies in social media. Marketing Intelligence \& Planning, 32(3), 328 344

Goodrich, K, Schiller, S.Z., Galletta, D. Consumer Reactions to Intrusiveness Of Online-Video Advertisements Do Length, Informativeness, and Humor Help (or Hinder) Marketing Outcomes? Journal of Advertising Research

Hajli.M (2014) "A study of the impact of social media on consumers."International Journal of Market Research 56 (3) : pp. 387-404.

Handayani N (2019), The Relationship between Product Browsing on Instagram and Shopping Motivation, and its Effects on Purchase Intention, Word-of-mouth Intention and Impulse Buying, International Journal of Scientific and Engineering Research, Volume 10, Issue 1, pp 1234-1238.

Heinrichs, J. H., Lim, J-S. \& Lim, K-S. (2011). Influence of Social Networking Site and User Access Method on Social Media Evaluation. Journal of Consumer Behaviour, 10, 347-355.

Hoch, S.J. \& Loewenstein, G.F. (1991). Timeinconsistent preferences and consumer self control. Journal of Consumer Research, 17(4), 492-507

Hristodoulakis.E, Karimalis.N, Matiatou.M, Angouras.V and Loukidou.E (2015), Retrieving the communication economics underlying health campaigning in third world countries, Journal of content, community and communication, vol 2, 4-13.

Husnain m, Qureshi I, Fatima T and Akhtar W (2016), The Impact of Electronic Word-ofMouth on Online Impulse Buying Behavior: 
The Moderating role of Big 5 Personality Traits, Journal of Accounting and Marketing, Volume 5, Issue 4, pp 1-9.

Kathiravan C, Mahalakshmi P and Palanisamy V (2019), Online Impulse Buying Behavior of Consumer Triggered by Digital Marketing, International Journal of Recent Technology and Engineering, Volume 8, Issue 256, pp 648652.

Kazi A G, Khokhar A A, Qureshi P A B and Murtaza F (2019), The Impact of Social Media on Impulse Buying Behaviour in Hyderabad Sindh Pakistan, International Journal of Entrepreneurial Research, Volume 2, Issue 2, pp 8-12.

Khawaja L (2018), Factors Influencing Consumer Behavior Towards Impulse Buying, International Journal of Business and Management, Volume 6, Issue 6, pp 245-256.

Khorrami, M. S., \&Esfidani, M. R. (2015). The Effect of Situational Factors on Impulse Buying and Compulsive Buying: Clothing. International Journal of Management, Accounting and Economics, 2(8), pp 823-837.

Kucukemiroglu, S. \& Kara, A. (2015). Online word-of-mouth communication on social networking sites: An empirical study of Facebook users. International journal of Commerce and management, 25(1), 2-20

Kumar S and Kaur A (201), Understanding Online Impulsive Buying Behaviour of Students, International Journal of Management Studies, Volume 5, Issue 3, pp 61-70.

Kumar, M. R., \& Narayanan, A. G. V. (2016). Effect of impulse buying on socioeconomic factors and retail categories. Indian Journal of Marketing, 46(9), pp 24-34.

Lim, P. L., \&Yazdanifard, R. (2015). What internal and external factors influence impulsive buying behavior in online shopping?. Global Journal of Management and Business Research.

Lins, S. (2013). To think, to feel, to have: The effects of need for cognition, hedonism and materialism on impulse buying tendencies in adolescents, Journal of European Psychology Students, pp 25-30.

Lipsman, A., Mudd, G., Rich, M. \&Bruich, S. (2012). The power of "like". How brands reach (and influence) fans through social-media marketing. Journal of Advertising Research, 52(1), 40-52

Lo, L. Y. S., Lin, S. W., \& Hsu, L. Y. (2016). Motivation for online impulse buying: A twofactor theory perspective. International Journal of Information Management, 36(5), 759-772.

Lu P H and Su C S (2019), A Study of the factors influencing customers impulse buying behaviour in restaurants, Advances in Hospitality and Tourism Research, Volume 6, Issue 1, pp 47-67.

Luniya, P., \&Verghese, M. (2015). A study on impulse buying and its determinants: A literature review. Pacific Business Review International, 8(1), pp 66-69.

Mainali, Y., Shakya, A., \& Pandey, P (2016), Impulse Buying Behavior of College Student in Kathmandu Valley, Advances in Economics and Business Management, Volume 3, Issue 6, pp 608-611.

Mir, I. \& Zaheer, A. (2012). Verification of Social Impact Theory Claims in Social Media Context. Journal of Internet Banking and Commerce, 17(1): 1-15

Moreno, F.M., Lafuente, J.G., Carreón, F.A., and Moreno, S. M. (2017). The Characterization of the Millennials and Their Buying Behavior. International Journal of Marketing Studies, 9 (5)

Muruganantham, G, Bhakat, R.B. (2013). A Review of Impulse Buying Behavior. International Journal of Marketing Studies, 5(3), pp. 149-160.

Niazi, G.S.K., Siddiqui, J, Shah, B.A., Hunjra, A.I. (2012). Effective Advertising and its Influence on Consumer Buying Behavior. Information Management and Business Review, 4(3), pp. 114-119.

Ozer, L., \& Gultekin, B. (2015). Pre-and postpurchase stage in impulse buying: The role of mood and satisfaction. Journal of retailing and consumer services, 22, 71-76.

Pashkevich, M., Dorai-Raj, S., Kellar, M., \&Zigmond, D. (2012). Empowering online advertisements by empowering viewers with the right to choose: the relative effectiveness of skippable video advertisements on YouTube. Journal of advertising research, 52(4), pp. 451457. 
Patel. S, (2015), "The research paradigm methodology, epistemology and ontology explained in simple language", Article on Research Methods - Research Paradigm

Perera, K.J.T. and J, Sutha. (2018). Factors Influence on Consumers' Leisure Shopping Behaviour in Shopping Malls and Its Future Research Direction-Literature Review. International Journal of Scientific and Research Publications, 8 (2), 203-217.

Rook, D. W., \& Hoch, S. J., "Consuming impulses," Advances in consumer research, 12(1), 23-27(1985)

Sahai S, Goel R, Garg V and Vinaik A (2019), Impact of Digitization on Impulse BuyingWhat Makes the Customer Bite the Bait, International Journal of Innovative Technology and Exploring Engineering, Volume 8, Issue 7, pp 2948-2951.

Satrianaa, R., (2014). Factor Analysis of Online Clothes Fashion Purchase on Social Media Instagram.European Journal of Economics and Management, 1 (1), 1-9.

Sebayang B A P T, Girsang A C and Negoro D A (2019), Analysis of Hedonic Shopping Motivation on Impulse Buying Effect of Millennial Generations in Jakarta, International Journal of Social Relevance and Concern, Volume 7, Issue 4, pp 8-12.

Seung-A, A.J. (2012). The potential of social media for luxury brand management. Marketing Intelligence \& Planning, 30(7), 687699.

Shafique, M. N., Kiani, I., Ahmad, N., \&Ibrar, M. (2015). Exploring relationship among factors of virtual communities, trust and buying in Pakistan. International Letters of Social and Humanistic Sciences, 49, pp 115122.

Sharma, B. K., Mishra, S., \& Arora, L. (2018). Does Social Medium Influence Impulse Buying of Indian Buyers? Journal of Management Research, 18(1), pp 27-36.

Singh, S. (2018). A Comprehensive Structural Equation Modeling for E-impulse Buying. Academy of Marketing Studies Journal.

Singh, S. C., \& Tandon, J. K. (2016). Understanding of Factors Related to Impulse Buying Behaviour of Consumers in the Shopping Malls of Jaipur City. International
Journal of Engineering and Management Research (IJEMR), 6(1), pp 423-429.

Tang T and Hao L (2017), Research on the Influence of Price Promotion on Consumer Purchase Decision under Network Environment, Atlantis Press, pp 220-224.

Thomas A K (2015), The Impact of Visual Merchandising, on Impulse Buying Behavior of Retail Customers, International Journal for Research in Applied Sciences and Engineering Technology, Volume 6, Issue 2, pp 474-490.

Thompson, E. R., \& Prendergast, G. P. (2015). The influence of trait affect and the five-factor personality model on impulse buying. Personality and Individual Differences, 76, 216-221.

Triwidisari, A., Nurkhin, A., \& Muhsin, M. (2017). The Relationships Between Instagram Social Media Usage, Hedonic Shopping Motives and Financial Literacy on Impulse Buying. Dinamika Pendidikan, 12(2), 170-181.

Ustanti M (2018), Effect of Shopping Lifestyle, Hedonic Shopping On Impulse Buying Behaviour Community Middle Class on Online Shopping, IOSR Journal of Business and Management, Volume 20, Issue 8, pp 8-11.

Vasanthi T and Deepa V (2016), Impulse Buying Behaviour of Women-An Analytical Study, Intercontinential Journal of Marketing Research Review, Volume 4, Issue 10, pp 2833.

Vohs, K. D., \& Faber, R. J. (2007). Spent Resources: Self-Regulatory Resource Availability Affects Impulse Buying. Journal of Consumer Research, 33(4), pp. 537-547

Wahab Z, Shihab M S, Hanafi A and Febria H $\mathrm{M}$

(2018), The Influence Of Online Shopping Motivation And Product Browsing Toward Impulsive Buying Of Fashion Products On A Social Commerce, International Journal of Scientific and Research Publications, Volume 8, Issue 7, pp 402-405.

Ye, L. \& Ki, E. J. (2017). Organizational crisis communication on Facebook: a study of BP's Deepwater Horizon oil spill. Corporate Communications: An International Journal, 22(1)

Yu, H., Zhang, R., \& Liu, B. (2018). Analysis on Consumers' Purchase and Shopping WellBeing in Online Shopping Carnivals with Two 
MotivationalDimensions. Sustainability, 10(12), 4603.

Zembik.M .(2014) "Social media as a source of knowledge for customers and enterprises." Online Journal of Applied Knowledge Management 2.2 :pp 132-148
Zhou, H., \& Gu, Z. (2015). The effect of different price presentations on consumer impulse buying behavior: The role of anticipated regret. American Journal of Industrial and Business Management, 5(01), 27 